African Crop Science Journal by African Crop Science Society is licensed under a Creative Commons Attribution 3.0 Uganda License. Based on a work at www.ajol.info/ and www.bioline.org.br/cs DOI: http://dx.doi.org/10.4314/acsj.v24i1.15S

\title{
MICROBIOLOGICAL SAFETY AND QUALITY OF DRIED CASSAVA CHIPS AND FLOUR SOLD IN THE NAIROBI AND COASTAL REGIONS OF KENYA
}

\author{
P.K. GACHERU, G.O. ABONG', M.W. OKOTH, P.O. LAMUKA, S.A. SHIBAIRO \\ and C.K.M. KATAMA ${ }^{1}$ \\ University of Nairobi, P. O. Box 29053-00625, Nairobi, Kenya \\ ${ }^{1}$ Kenya Agricultural and Livestock Research Organization, Mtwapa, Kenya \\ Corresponding author: gacherupatrick@gmail.com
}

\begin{abstract}
Cassava (Manihot esculenta Crantz) is rich in carbohydrates and is the third most important source of calories, in the tropics. The handling and processing practices of cassava roots expose them to microbial contamination. The objective of this study was to assess the level of contamination of cassava products that are in markets so as to establish the safety for human consumption. Samples from Nairobi and Coastal region of Kenya were evaluated for: total count, Staphylococcus aureus, total coliforms, yeast and mould and E. coli to establish their safety and quality for human consumption. Results for dried cassava chips showed; TVC 5.16-8.04 $\operatorname{log~cfu~g}$ g $^{-1}$; 4.81-7.21 $\log \mathrm{cfu} \mathrm{g}^{-1}$, mould 1.00-3.86 $\log _{\mathrm{cfu} \mathrm{g}}{ }^{-1} ; 1.00-3.28 \operatorname{log~cfu~g}^{-1}$ and Staphylococcus aureus 2.69-4.36 $\log \mathrm{cfu}$ ${ }^{-1} ; 2.90-4.71 \operatorname{log~cfu}^{-1}$ for Nairobi and Coastal region respectively. Cassava flour was; TVC 5.66-7.67 $\operatorname{log~cfu~g}{ }^{-1}$; 5.92-8.12 log cfu g ${ }^{-1}$, mould 1.00-6.73 $\log _{\mathrm{cfu} \mathrm{g}}{ }^{-1} ; 2.65-5.08 \mathrm{log}_{\mathrm{cfu} \mathrm{g}}{ }^{-1}$, Staphylococcus aureus 3.77-5.79 $\log \mathrm{cfu}$ $\mathrm{g}^{-1} ; 1.00-5.73 \log _{\mathrm{cfu} \mathrm{g}}{ }^{-1}$, and coliforms 0-6.34; 2.00-6.27 $\mathrm{log} \mathrm{cfu} \mathrm{g}^{-1}$ for Nairobi and Coastal regions respectively. One sample tested positive for presence of $E$. coli. Eighty seven percent of cassava flour and $77 \%$ of dried cassava chips samples were confirmed for presence of Staphylococcus aureus. There was a significant $(\mathrm{P}<0.05)$ difference in the microbial counts among the dried cassava chips samples and the cassava flour samples from markets in Nairobi and Mombasa. Results indicate excessive manual and poor post-harvest handling practices of the products hence, their poor quality and non-safety for consumption.
\end{abstract}

Key Words: Chips, contamination, Manihot esculenta

\section{RÉSUMÉ}

Manioc (Manihot esculenta Crantz) est riche en hydrates de carbone et est la troisième plus importante source de calories, sous les tropiques. Les pratiques de manipulation et de traitement des racines de manioc les exposent à la contamination microbienne. L'objectif de cette étude était d'évaluer le niveau de contamination des produits de manioc qui sont sur les marchés afin d'établir la sécurité pour la consommation humaine. Les échantillons provenant de Nairobi et de la région côtière du Kenya ont été évalués pour: nombre total, Staphylococcus aureus, coliformes totaux, levures et moisissures et $E$. coli pour établir leur sécurité et de qualité pour la consommation humaine. Résultats pour les cossettes de manioc séchées ont montré; TVC de 5,16 à $8,04 \log$ ufc g$^{-1} ; 4,81$ à 7,21 $\log$ ufc g-1 moule de 1,00 à $3,86 \log$ ufc g ${ }^{-1} ; 1,00$ à $3,28 \log$ ufc g-1 et Staphylococcus aureus 2,69 à 4,36 $\log$ ufc $^{-1}$; 2,90 à 4,71 log ufc ${ }^{-1}$ pour Nairobi et de la région côtière, respectivement. La farine de manioc était; TVC 5,66 à $7,67 \log$ ufc g ${ }^{-1} ; 5,92$ à $8,12 \log$ ufc g $^{-1}$, moule de 1,00 à $6,73 \log$ ufc g ${ }^{-1} ; 2,65$ à 5,08 log ufc g-1, Staphylococcus aureus 3,77 à $5,79 \log$ ufc g ${ }^{-1} ; 1,00$ à 5,73 log ufc g-1, et les coliformes 0 à 6,34; 2.00-6.27 log ufc g-1 pour Nairobi et côtières des régions respectivement. Un échantillon a été testé positif pour la présence de $E$. coli. Quatre-vingtsept pour cent de farine de manioc et $77 \%$ des échantillons séchés chips de manioc ont été confirmées pour la présence de Staphylococcus aureus. Il y avait une différence significative $(\mathrm{P}<0,05)$ dans les comptes microbiens parmi les cossettes de manioc échantillons séchés et les échantillons de farine de manioc en provenance des 
marchés à Nairobi et Mombasa. Les résultats indiquent manuelles et mauvaises pratiques excessives de manutention post-récolte des produits donc, leur mauvaise qualité et non-sécurité pour la consommation.

Mots Clés: Chips, contamination, Manihot esculenta

\section{INTRODUCTION}

Cassava (Manihot esculenta Crantz) significantly contributes to food security, incomes and employment opportunities in the rural areas of sub-Saharan Africa (Githunguri et al., 2007). About $38 \%$ of the cassava produced in the coastal lowlands of Kenya is consumed at household level, and $51 \%$ of the farmers make dried chips for domestic use, sale to starch and feed factories or as an intermediate for production of flour (Kiura et al., 2005).

Microbial deterioration and unfavorable biochemical changes of cassava roots are caused by physiological reactions and activities of microorganisms, which enter cassava roots through bruises and cuts caused during harvesting. Traditional processing of cassava chips and flour is generally unhygienic. The chips are sun-dried in open surfaces such as on flat rocks, roads, flat rooftops, flat baskets, or bare ground (FAO, 2005). Storage conditions after drying may also be of high humidity, thus leading to an increase in moisture levels hence creating conducive environments for growth and proliferation of microorganisms. Unhygienic conditions during production (for instance lack of protective clothing, lack of hand washing areas, drying on dirty surfaces), storage and slow sun-drying especially during the rainy seasons, often results in bacteria and mould contamination (Chiona et al., 2014), with for instance Aspergillus species that produce aflatoxins which are a major health concern to humans and livestock (Manjula et al., 2009). The presence of Staphylococcus aureus and Escherichia coli indicates unhygienic standards, excessive personnel handling and use of poor quality water during processing, postprocessing handling and marketing (Obadina et al., 2008). The objective of this study was to assess the level of contamination of cassava products that are in markets so as to establish the safety for human consumption.

\section{MATERIALS AND METHODS}

Sampling. Markets in the urban and densely populated cities of Nairobi and Mombasa of Kenya were purposively identified and selected. The cities were selected since they are focal areas for the purchase of foods and have a wide range of food products due to populace of the cities. Sampling in the markets was random and the number of samples collected was according to availability, thus ensuring exhaustive sampling. Thirteen dried cassava chips and 23 cassava flour samples were purchased from the selected markets in the study sites. The dried cassava chips samples from Nairobi were collected from Gikomba (GIK) market and Kawangware (KAW) markets and Mombasa from Kongowea (KON) and Majengo (MAJ) markets.

Microbial determination. Total viable counts (TVC), yeast and moulds, S. aureus, total coliforms and confirmatory tests were done according to Harrigan and McCance (1976).

Statistical analysis. All the data was subjected to analysis of variance (ANOVA) and the means separated by Fisher's protected test using Genstat 15th Edition. The significance level was set at $\mathrm{P}=0.05$.

\section{RESULTS AND DISCUSSION}

The standards Codex 176-1989 (CAC, 2013); EAS 739:2010; cassava chips specification and EAS 740:2010; on cassava flour specification set acceptable microbiological limits are total viable count of $5.00 \log \mathrm{cfu} \mathrm{g}^{-1}$, mould maximum limit of $3.00 \log \mathrm{cfu} \mathrm{g}^{-1}$, and $S$. aureus limits $2.00 \log \mathrm{cfu}$ $\mathrm{g}^{-1}$. Coliforms should be absent from the foods.

Table 1 shows results of microbial counts of dried cassava chips sampled from different traders in the two study sites; Nairobi and Mombasa. 
TABLE 1. Microbial count of dried cassava chips from Nairobi and Mombasa markets

\begin{tabular}{llccc}
\hline Sample/market & Region & TVC $($ log cfu g-1) & $\begin{array}{c}\text { Yeast and mould } \\
\left(\log c f u g^{-1}\right)\end{array}$ & $\begin{array}{c}\text { Staphylococcus } \\
\text { aureus }(\log \text { cfu g-1 }\end{array}$ \\
\hline GIK 1 & Nairobi & $7.19 \pm 0.00^{\mathrm{f}}$ & $1.00 \pm 0.00^{\mathrm{a}}$ & $3.93 \pm 0.01^{\mathrm{c}}$ \\
GIK 2 & Nairobi & $5.92 \pm 0.11^{\mathrm{c}}$ & $2.15 \pm 0.21^{\mathrm{b}}$ & $2.69 \pm 0.12^{\mathrm{a}}$ \\
GIK 3 & Nairobi & $5.61 \pm 0.02^{\mathrm{b}}$ & $2.00 \pm 0.00^{\mathrm{b}}$ & $3.03 \pm 0.11^{\mathrm{b}}$ \\
GIK 4 & Nairobi & $5.16 \pm 0.06^{\mathrm{a}}$ & $1.00 \pm 0.00^{\mathrm{a}}$ & $2.69 \pm 0.12^{\mathrm{a}}$ \\
GIK 6 & Nairobi & $8.04 \pm 0.01^{\mathrm{h}}$ & $1.00 \pm 0.00^{\mathrm{a}}$ & $4.36 \pm 0.03^{\mathrm{d}}$ \\
GIK 8 & Nairobi & $6.17 \pm 0.08^{\mathrm{d}}$ & $2.15 \pm 0.21^{\mathrm{b}}$ & $3.92 \pm 0.11^{\mathrm{c}}$ \\
KAW 1 & Nairobi & $6.95 \pm 0.01^{\mathrm{e}}$ & $2.00 \pm 0.00^{\mathrm{b}}$ & $4.27 \pm 0.02^{\mathrm{d}}$ \\
KAW 2 & Nairobi & $7.54 \pm 0.07^{\mathrm{d}}$ & $3.86 \pm 0.02^{\mathrm{c}}$ & $4.31 \pm 0.05^{\mathrm{d}}$ \\
KON 1 & Mombasa & $6.14 \pm 0.04^{\mathrm{c}}$ & $3.28 \pm 0.03^{\mathrm{c}}$ & $4.58 \pm 0.18^{\mathrm{c}}$ \\
KON 2 & Mombasa & $6.53 \pm 0.05^{\mathrm{d}}$ & $3.10 \pm 0.02^{\mathrm{b}}$ & $4.71 \pm 0.07^{\mathrm{c}}$ \\
KON 3 & Mombasa & $7.21 \pm 0.11^{\mathrm{e}}$ & $1.00 \pm 0.00^{\mathrm{a}}$ & $2.90 \pm 0.00^{\mathrm{a}}$ \\
KON 4 & Mombasa & $5.89 \pm 0.02^{\mathrm{b}}$ & $3.07 \pm 0.10^{\mathrm{b}}$ & $3.76 \pm 0.13^{\mathrm{b}}$ \\
MAJ1 & Mombasa & $4.81 \pm 0.05^{\mathrm{a}}$ & $1.00 \pm 0.00^{\mathrm{a}}$ & $3.00 \pm 0.06^{\mathrm{a}}$ \\
\hline
\end{tabular}

Values $=$ Means \pm Standard deviation in duplicates; Means in the same column with different superscripts are significantly different $(\mathrm{P}<0.05)$. TVC $=$ Total viable count

There was a significant $(\mathrm{P}<0.05)$ difference in the microbial counts in the dried cassava chips samples from markets in Nairobi and Mombasa. The total viable sample counts of dried cassava chips from Nairobi and Mombasa markets ranged from 5.16-8.04 $\log \mathrm{cfu} \mathrm{g}^{-1}$ and 4.81-7.21 log cfu $\mathrm{g}^{-1}$, respectively. These ranges are above the acceptable limits in the East African standards. The high bacterial load may be due to harvesting methods that cause injury to the roots hence providing a passage area for the bacteria. Also, the postharvest handling of cassava roots, particularly during the drying, where cassava is in direct contact with insects, dirt and animals increases the chances of contamination thus, increased microbial loads.

Mould counts in dried cassava chips. Yeast and mould count of dried cassava chips samples collected in Nairobi and Mombasa ranged from 1.00 to $3.86 \log$ cfu g $^{-1}$ and 1.00 to $3.28 \log$ cfu $\mathrm{g}^{-1}$, respectively. The yeast and mould counts reported in $87.5 \%$ of dried cassava chips from Nairobi were below the set limit of $3.00 \log$ cfu $\mathrm{g}^{-1}$ in the EAS 739:2010. This is attributed to drying of the cassava chips to the optimum level as the samples had moisture content that was below $12 \%$ set by the Codex Alimentarius
Commission (CAC). Low moisture levels of $<12 \%$ limit mould growth, this was also reported in a study by Aryee et al. (2006).

Sixty percent of the samples of dried cassava chips collected in the coastal city of Mombasa had yeast and mould counts that were above the set limit of $3.00 \log \mathrm{cfu} \mathrm{g}^{-1}$ in the standard EAS 739:2010 and may be attributed to the moisture content in the chips that ranged between $10.15 \%$ $11.57 \%$. The relatively higher moisture content of the cassava chips in Mombasa may be attributed to the high humidity experienced in the area, thus providing a more conducive growth environment for moulds. The significance of low moisture contents in foods cannot be overemphasized as they help to enhance the shelve life of food samples and prevent rapid spoilage by microorganisms (Uriah and Izuagbe, 1990). It is important to note the high perishable nature of the cassava roots means that they are easily contaminated by fungi (Wareing et al., 2001). In a study by Kaaya and Eboku (2010) samples collected were found to be contaminated with Penicillium (22.2\%), Aspergillus (20.4\%), and Fusarium species $(5.6 \%)$. Fungal contamination can lead to discoloration of the chips, give rise to mouldy taste and produce off odours (Gwinner et al., 1996). 
Staphylococcal counts in dried cassava chips. Staphylococcal count of dried cassava chips samples collected in Nairobi and Mombasa ranged from 2.69-4.36 to 2.90-4.71 log cfu g-1 (Table 1). The staphylococcal species reported in dried cassava chips were high compared to the acceptable limits set at $2.00 \log _{\text {cfu g }}{ }^{-1}$ by the EAS 739:2010 and 77\% of samples were confirmed for presence of Staphylococcus aureus. The contamination with this organism is attributed to post-processing handling and exposure both at the processing sites and in the markets (Obadina et al., 2008). This is because drying is usually done in open air where animals are reared. Guthrie (1983) intimated that large numbers of Staphylococcus cells (5.69-6.69 log $\mathrm{cfu}^{-1}$ ) are necessary for disease symptoms to be manifested, this then indicates that at the levels reported in this study, the risk of causing disease is low but not eliminated.
Table 2 shows the results of microbial count for cassava flour sampled from traders in five markets in Nairobi: Gikomba (GIK), Githurai (GIT), Kawangware (KAW), Muthurwa (MUT) and Uthiru (UT) markets and two markets in Mombasa; Marikiti (MA) and Majengo (MJ). There were significant $(\mathrm{P}<0.05)$ difference in the microbial counts in the cassava flour samples amongst the traders in the markets in Nairobi and Mombasa (Table 2).

Total viable counts. Total viable count of cassava flour sampled ranged from 5.66-7.67 log $\mathrm{cfu} \mathrm{g}^{-1}$ and 5.92-8.12 $\operatorname{log~cfu~g~}^{-1}$. The high TVC reported in cassava flour (Table 2) sampled from markets of both the study sites were above the acceptable set limits by the East African Standards EAS 740:2010. These results agree with a study by Ogori and Gana (2013). The significant high bacteria load reported in this study may be due

TABLE 2. Microbial count in cassava flour from Nairobi and Mombasa markets

\begin{tabular}{|c|c|c|c|c|c|}
\hline Sample/market & Region & TVC $\left(\log c f u g^{-1}\right)$ & $\begin{array}{l}\text { Yeast and mould } \\
\quad\left(\log \mathrm{cfu} \mathrm{g}^{-1}\right)\end{array}$ & $\begin{array}{l}\text { Staphylococcus aureus } \\
\left(\log c f u ~ g^{-1}\right)\end{array}$ & $\begin{array}{c}\text { Total coliforms } \\
\left(\log c f u g^{-1}\right)\end{array}$ \\
\hline GIK 1 & Nairobi & $5.66 \pm 0.03^{a}$ & $1.00 \pm 0.00^{a}$ & $5.08 \pm 0.07^{d}$ & $0.00 \pm 0.00^{\mathrm{a}}$ \\
\hline GIK 2 & Nairobi & $6.81 \pm 0.04^{c}$ & $3.90 \pm 0.07^{f}$ & $3.77 \pm 0.10^{\mathrm{a}}$ & $5.76 \pm 0.03^{i}$ \\
\hline GIK 3 & Nairobi & $7.06 \pm 0.01$ def & $4.26 \pm 0.21^{9}$ & $3.87 \pm 0.04^{a}$ & $6.27 \pm 0.08^{m}$ \\
\hline GIK 4 & Nairobi & $6.67 \pm 0.07^{b}$ & $3.66 \pm 0.11^{\mathrm{e}}$ & $4.56 \pm 0.06^{b}$ & $6.06 \pm 0.08^{k}$ \\
\hline GIK 5 & Nairobi & $7.62 \pm 0.00^{j}$ & $2.97 \pm 0.10^{b}$ & $5.38 \pm 0.03^{e}$ & $5.00 \pm 0.01^{d}$ \\
\hline GIK 6 & Nairobi & $7.06 \pm 0.03^{\mathrm{ef}}$ & $3.96 \pm 0.02^{f}$ & $4.45 \pm 0.07^{b}$ & $6.34 \pm 0.02^{n}$ \\
\hline GIT 1 & Nairobi & $7.31 \pm 0.00^{\mathrm{h}}$ & $4.53 \pm 0.03^{h}$ & $5.79 \pm 0.02^{\mathrm{g}}$ & $5.42 \pm 0.00^{f}$ \\
\hline KAW 1 & Nairobi & $7.22 \pm 0.04^{9}$ & $5.91 \pm 0.03^{j}$ & $5.44 \pm 0.08^{e}$ & $6.15 \pm 0.00^{\prime}$ \\
\hline KAW 3 & Nairobi & $6.98 \pm 0.04^{\mathrm{de}}$ & $6.71 \pm 0.04^{k}$ & $5.48 \pm 0.00^{\text {ef }}$ & $0.00 \pm 0.00^{\mathrm{a}}$ \\
\hline KAW 4 & Nairobi & $6.85 \pm 0.03^{c}$ & $6.73 \pm 0.00^{k}$ & $4.37 \pm 0.24^{b}$ & $5.68 \pm 0.03^{h}$ \\
\hline KAW 5 & Nairobi & $7.49 \pm 0.03^{i}$ & $3.24 \pm 0.09^{c}$ & $5.83 \pm 0.04^{9}$ & $5.94 \pm 0.00^{j}$ \\
\hline KAW 6 & Nairobi & $7.67 \pm 0.08^{j}$ & $5.55 \pm 0.03^{i}$ & $4.80 \pm 0.10^{c}$ & $5.81 \pm 0.00^{i}$ \\
\hline MUT 1 & Nairobi & $7.10 \pm 0.00^{f}$ & $4.69 \pm 0.07^{\mathrm{h}}$ & $5.65 \pm 0.00^{\text {fg }}$ & $4.78 \pm 0.00^{c}$ \\
\hline UTH 1 & Nairobi & $7.04 \pm 0.08^{\text {def }}$ & $3.52 \pm 0.00^{\mathrm{de}}$ & $5.11 \pm 0.12^{d}$ & $5.58 \pm 0.00^{9}$ \\
\hline UTH 2 & Nairobi & $7.61 \pm 0.05^{j}$ & $5.46 \pm 0.11^{i}$ & $5.01 \pm 0.16^{\mathrm{cd}}$ & $4.60 \pm 0.00^{b}$ \\
\hline UTH 3 & Nairobi & $7.00 \pm 0.06^{\mathrm{de}}$ & $4.26 \pm 0.12^{g}$ & $5.00 \pm 0.13^{\mathrm{cd}}$ & $5.33 \pm 0.00^{\mathrm{e}}$ \\
\hline UTH 4 & Nairobi & $6.96 \pm 0.02^{d}$ & $3.45 \pm 0.05^{d}$ & $4.86 \pm 0.11^{c}$ & $0.00 \pm 0.00^{\mathrm{a}}$ \\
\hline MAR1 & Mombasa & $6.40 \pm 0.01^{b}$ & $4.08 \pm 0.02^{c}$ & $3.02 \pm 0.09^{b}$ & $3.30 \pm 0.00^{b}$ \\
\hline MAJ 1 & Mombasa & $5.92 \pm 0.01^{a}$ & $2.65 \pm 0.07^{a}$ & $4.34 \pm 0.03^{c}$ & $2.00 \pm 0.00^{\mathrm{a}}$ \\
\hline MAJ 2 & Mombasa & $7.32 \pm 0.04^{c}$ & $3.68 \pm 0.09^{b}$ & $5.28 \pm 0.03^{d}$ & $6.20 \pm 0.07^{d}$ \\
\hline MAJ 3 & Mombasa & $8.12 \pm 0.03^{d}$ & $3.64 \pm 0.01^{b}$ & $5.28 \pm 0.01^{d}$ & $6.27 \pm 0.02^{d}$ \\
\hline MAJ 4 & Mombasa & $5.94 \pm 0.10^{a}$ & $2.69 \pm 0.12^{\mathrm{a}}$ & $1.00 \pm 0.00^{\mathrm{a}}$ & $4.00 \pm 0.00^{c}$ \\
\hline MAJ 5 & Mombasa & $7.18 \pm 0.12^{c}$ & $5.08 \pm 0.09^{d}$ & $5.73 \pm 0.10^{e}$ & $6.23 \pm 0.01^{d}$ \\
\hline
\end{tabular}

Means \pm Standard deviation; Means in the same column with different superscripts are significantly different $(P<0.05)$. TVC $=$ Total viable count 
to poor drying and processing methods. The cassava roots that are dried may be contaminated during harvesting, where the tools used for purposes of harvesting are dirty and contaminated hence cross-contamination occurs. Tools used to harvest the cassava roots may also injure the cassava roots thus making the freshly harvested root susceptible to microbial attack. Furthermore, dried cassava chips that are an intermediate to the production of cassava flour are generally dried on surfaces that are prone to contamination from animals, faecal matter, dust and insects. These high levels of contamination make the cassava flour non-safe for consumption by consumers in Kenya, as they may contribute to food borne diseases.

Mould counts in cassava flour. The yeast and mould count ranged from 1.00-6.73 $\log \mathrm{cfu} \mathrm{g}^{-1}$ to $2.65-5.08 \mathrm{log} \mathrm{cfu} \mathrm{g}^{-1}$. About $88 \%$ and $67 \%$ of the flour samples from Nairobi and Mombasa respectively had counts that were above what is set as the allowed maximum limit in flour standard. The results in this study agree with reports by Adebayo-Oyetoro et al. (2013), and Odetunde et al. (2014) that suggested high fungal growth in the samples of flour that were in markets in Nigeria. Several researchers (Kuku et al., 1984; Abba Kareem et al., 1991), isolated fungi Aspergillus fumigatus and Aspergillus niger from cassava flour.

These high mould counts may be attributed to the fact that flour is sold in open air markets and are displayed in jute bags lined with nylons thus prone to drizzling or droplets of water and spores of various species of moulds, which are heavily suspended in air, especially in an untidy and unhygienic environment. According to Odetunde et al. (2014) sporulating moulds easily get in contact with foods that are openly displayed. Moulds are potential spoilage agents (Uriah and Izuagbe, 1990) and cause off flavors in foods as well as changes in appearance of food (Elmer, 1990). The high mould counts reported in this study are an indication of potential spoilage agent and mycotoxins food poisoning (Reiss, 1978). The open display of cassava flour should be avoided, and instead put in containers that minimise exposure to the environment surrounding the markets.
Staphylococcal counts in cassava flour. The range for Staphylococcus counts of flour samples collected from markets in Nairobi Mombasa was 3.77-5.79 to $1.00-5.73 \log$ cfu g $^{-1}$, respectively. About $87 \%$ of cassava flour was confirmed for presence of S. aureus. Ogori and Gana (2013) reported presence of Staphylococcus species in flour made from dried cassava "chunks" (chips) in a study site in Nigeria that could produce toxins, that are a cause of external skin infection and potent infections, agreeing with results in this study. The reports of Liston and Matches (1976) and Guthrie (1983) confirmed that the most important sources of this organism in foods and beverages are the nasal canals and infected hands, and they constitute health hazards. Staphylococcal spores have ability to withstand high temperature and they produce enterotoxins which are not easily destroyed and may cause food poisoning; this then indicates that the cassava flour poses risks to consumers even after being subjected to heat during cooking, due to the possible non destruction of toxins that may be present in the flour.

Coliform counts in flour. Total coliform count in cassava flour samples ranged from $0.00-6.34$ to 2.00-6.27 log cfu g ${ }^{-1}$, respectively. These values indicated that $82.4 \%$ of the samples collected in the markets within the Nairobi had at least a presence of coliforms. One sample of flour collected from a market in Nairobi (GIK 4) confirmed positive for presence of $E$. coli. According to the East African Standard EAS 740:2010 no coliforms should be present in cassava flour. Flour samples from Nairobi and Mombasa were found to be heavily contaminated with coliforms; indicating poor hygienic conditions and faecal contamination during processing as well as likely during activities associated with selling for example packing and displaying the flour. Presence of coliforms in foods may indicate that foods were exposed to conditions favourable for the introduction and growth of pathogenic organisms (Odetunde et al., 2014). These results correspond to what was reported by Odetunde et al. (2014) in Nigeria. High counts in cassava flours may be due to coliform proliferation from the atmosphere (Okpokeri et al., 1985).The occurrence of lactose fermenters 
such as Escherichia coli suggests a degree of contamination with faecal discharges of human and animal origin (Refai, 1979; Uriah and Izuagbe, 1990; Olowoyo et al., 2001). The presence of these pathogenic microorganisms is thus an indication of microbial contamination with an incessant possibility of hazards to the health of man (Odetunde et al., 2014).

\section{CONCLUSION}

There is a high load of bacterial, Staphylococcus spp. and coliforms present in dried chips and cassava flour samples indicating excessive personnel handling and poor hygiene during post-harvest processing, handling and marketing. High mould counts in flour indicate poor storage practices in materials. Therefore, cassava chips and flours in the sampled markets are of low quality and may be unsafe for consumption. It is paramount that basic hygiene and sanitary rules should be observed in the whole of cassava production value chain. Proper training on good practices especially good hygiene; as well as equipping farmers and processors with more hygienic sun drying equipment and methods will lead to improved quality and safety of the cassava products available in the market.

\section{ACKNOWLEDGMENT}

This study was funded by the Eastern Africa Agricultural Productivity Project (EAAPP) and Kenya Agricultural and Livestock Research Organization (KALRO). This paper was published through the facilitation of the Association for Strengthening Agricultural Research in Eastern and Central Africa (ASARECA). Authors register their gratitude to all.

\section{REFERENCES}

Abba-Kareem, V.N., Okagbue, R.N. and Ogbadu, G.H. 1991. Production of aflatoxin by Aspergillus flavus in cassava flour. Nigeria Food Journal 8:87 - 91.

Adebayo-Oyetoro, A., Oyewole, O.O.B., Obadina, A.O. and Omemu, M.A. 2013. Microbiological safety assessment of fermented cassava flour "Lafun" available in Ogun and Oyo states of Nigeria. International Journal of Food Science 2013:1-5.

Aryee, F.N.A., Oduro, I., Ellis, W.O. and Afuakwa, J.J. 2006. The physicochemical properties of flour samples from the roots of 31 varieties of cassava. Food Control 17:916-922.

CAC. 2013. CODEX STAN 176-1989. Codex standard for edible cassava flour. Adopted 1989, revision 1995, amendment 2013.

Chiona, M., Ntawuruhunga, P., Benesi, I.R.M., Matumba, L. and Moyo, C.C. 2014. Aflatoxins contamination in processed cassava in Malawi and Zambia. African Journal of Food, Agriculture, Nutrition and Development 14(3):8809-8820.

Elmer, H.M. 1990. Mycotoxins. In: Deans, O. C. (Eds.), Food borne diseases. Academic Press. Santiago, California, USA. pp.138.

FAO. 2005. A review of cassava in Africa with country case studies on Niger, Ghana, the United Republic of Tanzania, Uganda and Benin. Validation forum on the global cassava Development strategy, April 26-28, Food and Agriculture Organization, Rome, Italy.

Githunguri, C.M., Mwiti, S. and Migwa, Y. 2007. Cyanogenic potentials of early bulking cassava planted at Katumani, a semi-arid area of Eastern Kenya. Africa Crop Science Conference Proceedings 8: 925 - 927.

Guthrie, R.H. 1983. Food sanitation. 2nd Ed. Avi Publishing Company Inc., Westport, Connecticut, U.S.A. 391pp.

Gwinner, J., Hamisch, R. and Much, O. 1996. Manuel sur la manutentionet la conservation des grains après récolte. [Manual handling and preservation of grain after harvest]. Deutsche Gesellschaftfür Technische Zusammenarbeit (GTZ), Eschborn, Germany. $368 \mathrm{pp}$.

Harrigan, W.F and McCance, E.M. 1976. Laboratory methods in food and dairy microbiology. Academic Press. London U.K. 31pp.

Kaaya, A.N. and Eboku, D. 2010. Mould and aflatoxin contamination of dried cassava chips in Eastern Uganda: association with traditional processing and storage practices. Journal of Biological Sciences 10(8):718 - 729. 
Kiura, J.N., Mutegi, C.K., Kibet, P. and Danda, M.K. 2005. Cassava production, utilization and marketing in Coastal Kenya. A report of a survey on cassava enterprise conducted between July and October 2003 in Kwale, Kilifi, Mombasa and Malindi Districts. Internal report no.35, KARLO-Mtwapa, Kenya.

Kuku, F.O, Afolabi, J.F. and Akoma, D.A. 1984. Moisture and mycoflora contents of cassava flour stored in plastic containers. Report of Nigerian stored Produce Institute, Technical Report No. 7. Ilorin, pp. 69-74.

Liston, J. and Matches, J., 1976. Fish crustaceans and precooked seafood's. En "Compendium of methods for microbiological examination of foods". cap. 40:507. American Public. Health Association (APHA). Washington. D.C., USA.

Manjula, K., Hell, K., Fandohan, P., Abass, A. and Bandyopadhyay, R. 2009. Aflatoxin and fumonisin contamination of cassava products and maize grain from markets in Tanzania and Republic of the Congo. Toxin Reviews 2:63 - 69.

Obadina, A.O., Oyewole, O.B., Sanni, L.O., Tomlins, K.I. and Westby, A. 2008. Identification of hazards and critical control points $(\mathrm{CCP})$ for cassava fufu processing in South-West Nigeria. Food Control 19(1):22 26.

Odetunde, S.K., Adebajo, L.O., Lawal, A.K. and Itoandon, E.E. 2014. Investigation into microbiological and chemical characteristics of cassava flour in Nigeria. Global Advanced Research Journal of Microbiology 3(3):031 040.
Ogori, A.F. and Gana, J. 2013. Microbiological loads of road side dried cassava flour from cassava balls and chunks. American Open Journal of Agricultural Research 7(1):24 39.

Okpokeri, A.O., Idoma, S.O. and Ejiofor, M.A.N. 1985. Product of processed cassava fufu. Nigerian Food Journal 2(2-3):145 - 148.

Olaoye, O.A., Onilude, A.A. and Idowu, O.A. 2006. Determination of the flocculating properties of tapioca in pharmaceutical suspensions. Journal on Raw material Research 2(2):34 - 42.

Olowoyo, O.O., Akinyosoye, F.A. and Adetuyi, F.C. 2001. Micro-organisms associated with some Cassava (Manihot esculenta Crantz) products. Journal of Research and Reviews in Sciences 2: 10-14.

Refai, M.K. 1979. Methods of microbiological analysis of food and water. Manual of Food and Agricultural Organization of the United Nations. FAO EC/Microbiology/75/Report I/ Annex V, FAO, Rome, Italy.

Reiss, J. 1978. Mycotoxin in food, fate of aflatoxin $\mathrm{B}$ during preparation and baking of whole wheat bread. Cereal Chemistry 55(4):421 - 423.

Uriah, N. and Izuagbe, Y. 1990. Water industries and public health microbiology. University of Benin Press. Benin City. pp. 18 - 24.

Wareing, P.W., Westby, A., Gibbs, J.A., Allotey, L.T. and Halm, M. 2001. Consumer preferences and fungal and mycotoxin contamination of dried cassava products from Ghana. International Journal of Food Science and Technology 36:1-10. 